\title{
Enzyme Inhibition by Molluscicidal Components of Myristica fragrans Houtt. in the Nervous Tissue of Snail Lymnaea acuminata
}

\author{
Preetee Jaiswal, Pradeep Kumar, V. K. Singh, and D. K. Singh \\ Department of Zoology, D.D.U. Gorakhpur University, Gorakhpur 273009, India \\ Correspondence should be addressed to D. K. Singh, dksingh_gpu@yahoo.co.in \\ Received 29 May 2009; Revised 30 August 2009; Accepted 15 September 2009 \\ Academic Editor: Qi-Zhuang Ye
}

Copyright () 2010 Preetee Jaiswal et al. This is an open access article distributed under the Creative Commons Attribution License, which permits unrestricted use, distribution, and reproduction in any medium, provided the original work is properly cited.

\begin{abstract}
This study was designed to investigate the effects of molluscicidal components of Myristica fragrans Houtt. (Myristicaceae) on certain enzymes in the nervous tissue of freshwater snail Lymnaea acuminata Lamarck (Lymnaeidae). In vivo and in vitro treatments of trimyristin and myristicin (active molluscicidal components of Myristica fragrans Houtt.) significantly inhibited the acetylcholinesterase (AChE), acid and alkaline phosphatase (ACP/ALP) activities in the nervous tissue of Lymnaea acuminata. The inhibition kinetics of these enzymes indicates that both the trimyristin and myristicin caused competitive noncompetitive inhibition of AChE. Trimyristin caused uncompetitive and competitive/noncompetitive inhibitions of ACP and ALP, respectively whereas the myristicin caused competitive and uncompetitive inhibition of ACP and ALP, respectively. Thus results from the present study suggest that inhibition of AChE, ACP, and ALP by trimyristin and myristicin in the snail Lymnaea acuminata may be the cause of the molluscicidal activity of Myristica fragrans.
\end{abstract}

\section{Introduction}

The snail Lymnaea acuminata Lamarck (Lymnaeidae) is the vector of liver flukes, Fasciola gigantica Cobbold (Fascioliodae) and Fasciola hepatica Linnaeus (Fascioliodae) which are responsible for endemic fascioliasis in cattle population of northern India $[1,2]$. One way to reduce the risk of fascioliasis is to delink the life cycle of the flukes by killing the vector snail $[3,4]$. Recently, it has been reported that Myristica fragrans (Myristicaceae) seed (nutmeg) and aril (mace) have potent molluscicidal activity against Lymnaea acuminata [5]. The active moieties responsible for the molluscicidal activity are trimyristin and myristicin [5]. The mechanism by which these active components cause snail death is not known. The present study is an extension of our previous study aimed at elucidating the effect of the active moieties on the different enzymes namely, acetylcholinesterase (AChE), acid phosphatase (ACP), and alkaline phosphatase (ALP) in the nervous tissue of snail Lymnaea acuminata.

\section{Materials and Methods}

2.1. Test Material. Trimyristin(1,2,3-tritetradecanoylglycerol) catalog no. T 5141, and myristicin (4-methoxy-6-(2-pro- penyl)-1,3-benzodioxole), catalog no. M 9411, were purchased from Sigma Chemical Co., USA.<smiles>C=CCc1cc(OC)c2c(c1)OCO2</smiles>

Myristicin

2.2. Bioassay. Adult Lymnaea acuminata (length, $2.25 \pm$ $0.20 \mathrm{~cm}$ ) were collected locally from Ramgarh Lake located almost adjacent to this University campus. Snails were acclimatized to laboratory conditions for 72 hours and used 
TABLE 1: In vivo effect of 24 and $96 \mathrm{~h}$ exposure to sublethal concentration of trimyristin and myristicin on acetylcholinesterase (AChE), acid phosphatase (ACP), and alkaline phosphatase (ALP) activities in the nervous tissue of Lymnaea acuminata.

\begin{tabular}{|c|c|c|c|c|c|c|}
\hline \multirow{2}{*}{ Enzyme } & \multirow{2}{*}{ Treatment } & \multicolumn{5}{|c|}{ Enzyme activity } \\
\hline & & Control & $\begin{array}{c}40 \% \text { of } 24 \mathrm{~h} \\
\mathrm{LC}_{50}\end{array}$ & $\begin{array}{c}80 \% \text { of } 24 \mathrm{~h} \\
\mathrm{LC}_{50} \\
\end{array}$ & $\begin{array}{c}40 \% \text { of } 96 \mathrm{~h} \\
\mathrm{LC}_{50}\end{array}$ & $\begin{array}{c}80 \% \text { of } 96 \mathrm{~h} \\
\mathrm{LC}_{50}\end{array}$ \\
\hline \multirow{2}{*}{ AChE } & Trimyristin & $0.73 \pm 0.0(100)$ & $0.66 \pm 0.0^{*}(90)$ & $0.60 \pm 0.0 *(82)$ & $0.53 \pm 0.0 *(73)$ & $0.46 \pm 0.0 *(63)$ \\
\hline & Myristicin & $0.73 \pm 0.0(100)$ & $0.57 \pm 0.0^{*}(78)$ & $0.52 \pm 0.0^{*}(71)$ & $0.45 \pm 0.0^{*}(62)$ & $0.36 \pm 0.0^{*}(49)$ \\
\hline \multirow{2}{*}{$\mathrm{ACP}$} & Trimyristin & $32.3 \pm 0.1(100)$ & $28.0 \pm 0.1^{*}(87)$ & $25.7 \pm 0.3^{*}(80)$ & $23.7 \pm 0.0^{*}(73)$ & $20.7 \pm 0.2 *(64)$ \\
\hline & Myristicin & $32.3 \pm 0.1(100)$ & $26.0 \pm 0.3^{*}(80)$ & $21.5 \pm 0.0 *(67)$ & $17.9 \pm 0.1 *(55)$ & $14.2 \pm 0.1 *(44)$ \\
\hline \multirow{2}{*}{ ALP } & Trimyristin & $30.0 \pm 0.1(100)$ & $27.5 \pm 0.1^{*}(92)$ & $25.0 \pm 0.1 *(84)$ & $21.4 \pm 0.1^{*}(71)$ & $18.2 \pm 0.2 *(61)$ \\
\hline & Myristicin & $30.0 \pm 0.1(100)$ & $22.8 \pm 0.1^{*}(76)$ & $19.8 \pm 0.1^{*}(66)$ & $17.7 \pm 0.1^{*}(59)$ & $15.7 \pm 0.2 *(52)$ \\
\hline
\end{tabular}

Values are mean \pm SE of six replicates. Values in parentheses indicate per cent of enzyme activity with control taken as $100 \%$.

Concentrations (w/v) have been expressed as final concentration in aquarium water. Acetylcholinesterase activity, $\mu \mathrm{mole}$ "SH" hydrolyzed min ${ }^{-1} \mathrm{mg}^{-1}$ protein.

Acid phosphatase activity, $\mu$ mole substrate hydrolyzed $30 \mathrm{~min}^{-1} \mathrm{mg}^{-1}$ protein.

Alkaline phosphatase activity, $\mu$ mole substrate hydrolyzed $30 \mathrm{~min}^{-1} \mathrm{mg}^{-1}$ protein.

* Significant $(P<.05)$ when $t$-test was used for locating difference between treated and control group of animals.

as experimental animals. Twenty experimental snails were kept in a glass aquarium containing $3 \mathrm{~L}$ of dechlorinated tap water at $22-24^{\circ} \mathrm{C}$. Six aquaria were set up for each concentration. Each set of experimental snails was exposed to sublethal concentrations -40 and $80 \%$ of $24 \mathrm{~h}$ and $96 \mathrm{~h} \mathrm{LC}_{50}$ of trimyristin $\left(24 \mathrm{~h}-6.21,12.43 \mathrm{mg} \mathrm{L}^{-1} ; 96\right.$ hours- 2.80, $5.60 \mathrm{mg} \mathrm{L}^{-1}$ ) and myristicin (24 hours- 0.60, $1.20 \mathrm{mg} \mathrm{L}^{-1}$; 96 hours $0.06,0.12 \mathrm{mg} \mathrm{L}^{-1}$ ) for 24 and 96 hours. These concentrations were based on 24 and 96 hours $\mathrm{LC}_{50}$ values earlier reported by us [5]. Control animals were kept in an equal volume of dechlorinated water under similar conditions without any treatment. After 24 and 96 hours of treatment snails were removed from the aquaria and rinsed with water. Nervous tissue, present around the buccal mass of the snail, was taken out for the measurement of AChE, ACP, and ALP activities in the treated and control groups of snails.

In vitro experiments were performed by dissolving the molluscicides in ether and an appropriate volume containing $3,5,7$, and $9 \mu \mathrm{g}$ of trimyristin and $0.3,0.5,0.7$, and $1.0 \mu \mathrm{g}$ of myristicin $(0.04,0.07,0.09,0.1$, and $0.15 \mathrm{mM}$ of trimyristin and $0.01,0.02,0.03,0.05$, and $0.09 \mathrm{mM}$ of myristicin) was added to $10 \mathrm{~mm}$ path length cuvette separately. Ether was then allowed to evaporate. Molluscicides were preincubated for 15 minutes at $25^{\circ} \mathrm{C}$ with an enzyme source and then enzyme activity was determined. The control cuvette contained ether only. The Michaelis-Menten constant $\left(K_{m}\right)$ and maximum velocity $\left(V_{\max }\right)$ of different enzyme inhibitions were calculated by nonlinear regression. Lineweaver-Burk plots for the hydrolysis of different concentrations of substrate by the treated $(0.09 \mathrm{mM}$ trimyristin and $0.03 \mathrm{mM}$ myristicin) and untreated enzymes were plotted to observe mode of enzyme inhibition [6]. $\mathrm{IC}_{50}$ values of myristicin and trimyristin were calculated in between the negative log concentration of inhibitor versus relative activity between inhibited and uninhibited enzymes.

\subsection{Enzyme Assay}

2.3.1. Acetylcholinesterase. Acetylcholinesterase (AChE) activity was measured by the method of Ellman et al. [7] as modified by Singh and Agarwal [8]. $50 \mathrm{mg}$ of nervous tissue of Lymnaea acuminata taken around the buccal mass was homogenized in $1.0 \mathrm{~mL}$ of $0.1 \mathrm{M}$ phosphate buffer $\mathrm{pH}$ 8.0 for 5 minutes in an ice bath and centrifuged at $1000 \mathrm{~g}$ for 30 minutes at $4^{\circ} \mathrm{C}$. The supernatant was used as an enzyme source. Enzyme activity was measured in a $10 \mathrm{~mm}$ path length cuvette using an incubation mixture consisting of $0.1 \mathrm{~mL}$ of enzyme source, $2.9 \mathrm{~mL}$ of $0.1 \mathrm{M}$ buffer $\mathrm{pH} 8$, $0.1 \mathrm{~mL}$ of chromogenic agent DTNB (5, $5^{\prime}$-dithio-bis-2nitrobenzoic acid), and $0.02 \mathrm{~mL}$ of freshly prepared ATChI (aetylthiocholine iodide) solution in distilled water. The change in optical density at $412 \mathrm{~nm}$ was recorded for 3 minutes after every $30 \mathrm{~s}$ interval at $25^{\circ} \mathrm{C}$. Enzyme activity has been expressed as $\mu$ mole "SH" hydrolyzed $\mathrm{min}^{-1}$ $\mathrm{mg}^{-1}$ protein. For the estimation of kinetic constants of $\mathrm{AChE}$, in vitro inhibition of the enzyme was carried out at different concentrations $\left(3.0 \times 10^{-4} \mathrm{M}, 5.0 \times 10^{-4} \mathrm{M}, 7.0 \times\right.$ $10^{-4} \mathrm{M}$, and $1.0 \times 10^{-3} \mathrm{M}$ ) of the substrate acetylthiocholine iodide.

2.3.2. Acid Phosphatase. Acid phosphatase (ACP) activity in the nervous tissue of Lymnaea acuminata was measured by the method of Bergmeyer [9] as modified by Singh and Agarwal [10]. Tissue homogenate $(2 \%, \mathrm{w} / \mathrm{v})$ was prepared in ice cold $0.9 \% \mathrm{NaCl}$ and centrifuged at $5000 \mathrm{~g}$ for 15 minutes at $4^{\circ} \mathrm{C}$. The supernatant was used as an enzyme source. $0.2 \mathrm{~mL}$ of enzyme source was added to $1.0 \mathrm{~mL}$ of acid buffer substrate $(0.41 \mathrm{~g}$ citric acid, $1.125 \mathrm{~g}$ sodium citrate, and $165 \mathrm{mg}$ 4-nitrophenyl phosphate sodium salt to $100 \mathrm{~mL}$ of double distilled water) preincubated at $37^{\circ} \mathrm{C}$ for 10 minutes. The incubation mixture was mixed thoroughly and incubated for 30 minutes at $37^{\circ} \mathrm{C} .4 \mathrm{~mL}$ of $0.1 \mathrm{~N}$ $\mathrm{NaOH}$ was then added to the incubation mixture. The yellow colour, developed due to the formation of 4-nitrophenol, was determined colorimetrically at $420 \mathrm{~nm}$. Standard curves were drawn with different concentrations of 4-nitrophenol. The ACP activity has been expressed as $\mu$ mole substrate hydrolyzed $30 \mathrm{~min}^{-1} \mathrm{mg}^{-1}$ protein. For the determination of kinetic constants of acid phosphatase, in vitro inhibition of the enzyme was carried out at different concentrations 
TABLE 2: In vitro effect of different concentrations ( $\mathrm{mM}$ ) of trimyristin and myristicin on the acetylcholinesterase (AChE), acid phosphatase (ACP), and alkaline phosphatase (ALP) activities in the nervous tissue of Lymnaea acuminata.

\begin{tabular}{|c|c|c|c|c|c|c|c|c|}
\hline \multirow[t]{2}{*}{ 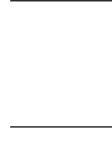 } & \multirow[t]{2}{*}{ Treatment } & \multicolumn{7}{|c|}{$\begin{array}{l}\text { Enzyme } \\
\text { activity }\end{array}$} \\
\hline & & Control & $0.04 \mathrm{mM}$ & $0.07 \mathrm{mM}$ & $0.09 \mathrm{mM}$ & $0.1 \mathrm{mM}$ & $0.15 \mathrm{mM}$ & $\mathrm{IC}_{50} \mathrm{mM}$ \\
\hline \multirow{4}{*}{ AChE } & \multirow[t]{2}{*}{ Trimyristin } & $\begin{array}{l}0.72 \pm 0.0 \\
\quad(100)\end{array}$ & $\begin{array}{c}0.60 \pm 0.0^{*} \\
(83)\end{array}$ & $\begin{array}{c}0.52 \pm 0.0^{*} \\
\quad(72)\end{array}$ & $\begin{array}{c}0.45 \pm 0.0^{*} \\
(63)\end{array}$ & $\begin{array}{c}0.38 \pm 0.0^{*} \\
(53)\end{array}$ & $\begin{array}{c}0.18 \pm 0.0^{*} \\
(25)\end{array}$ & 0.11 \\
\hline & & Control & $0.01 \mathrm{mM}$ & $0.02 \mathrm{mM}$ & $0.03 \mathrm{mM}$ & $0.05 \mathrm{mM}$ & $0.09 \mathrm{mM}$ & \\
\hline & \multirow[t]{2}{*}{ Myristicin } & $\begin{array}{l}0.72 \pm 0.0 \\
\quad(100)\end{array}$ & $\begin{array}{c}0.49 \pm 0.0 * \\
(68)\end{array}$ & $\begin{array}{c}0.42 \pm 0.0^{*} \\
\quad(58)\end{array}$ & $\begin{array}{c}0.36 \pm 0.0^{*} \\
\quad(50)\end{array}$ & $\begin{array}{c}0.29 \pm 0.0^{*} \\
(40)\end{array}$ & $\begin{array}{c}0.11 \pm 0.0^{*} \\
(15)\end{array}$ & 0.03 \\
\hline & & Control & $0.04 \mathrm{mM}$ & $0.07 \mathrm{mM}$ & $0.09 \mathrm{mM}$ & $0.1 \mathrm{mM}$ & $0.15 \mathrm{mM}$ & \\
\hline \multirow{3}{*}{$\mathrm{ACP}$} & \multirow[t]{2}{*}{ Trimyristin } & $\begin{array}{c}39.7 \pm 0.1 \\
(100)\end{array}$ & $\begin{array}{c}35.5 \pm 0.1^{*} \\
(90)\end{array}$ & $\begin{array}{c}32.2 \pm 0.0^{*} \\
(81)\end{array}$ & $\begin{array}{c}27.9 \pm 0.0^{*} \\
(70)\end{array}$ & $\begin{array}{c}25.2 \pm 0.1^{*} \\
(64)\end{array}$ & $\begin{array}{c}8.1 \pm 0.1^{*} \\
(20)\end{array}$ & 0.16 \\
\hline & & Control & $0.01 \mathrm{mM}$ & $0.02 \mathrm{mM}$ & $0.03 \mathrm{mM}$ & $0.05 \mathrm{mM}$ & $0.09 \mathrm{mM}$ & \\
\hline & \multirow[t]{2}{*}{ Myristicin } & $\begin{array}{c}39.7 \pm 0.1 \\
\quad(100)\end{array}$ & $\begin{array}{c}33.6 \pm 0.2^{*} \\
(85)\end{array}$ & $\begin{array}{c}29.0 \pm 0.0^{*} \\
(73)\end{array}$ & $\begin{array}{c}25.8 \pm 0.0^{*} \\
(65)\end{array}$ & $\begin{array}{c}22.7 \pm 0.0^{*} \\
(57)\end{array}$ & $\begin{array}{c}7.2 \pm 0.2^{*} \\
(18)\end{array}$ & 0.07 \\
\hline \multirow{4}{*}{ ALP } & & Control & $0.04 \mathrm{mM}$ & $0.07 \mathrm{mM}$ & $0.09 \mathrm{mM}$ & $0.1 \mathrm{mM}$ & $0.15 \mathrm{mM}$ & \\
\hline & \multirow[t]{2}{*}{ Trimyristin } & $\begin{array}{l}35.0 \pm 0.2 \\
(100)\end{array}$ & $\begin{array}{c}33.0 \pm 0.0^{*} \\
(94)\end{array}$ & $\begin{array}{c}29.7 \pm 0.2^{*} \\
(85)\end{array}$ & $\begin{array}{c}26.7 \pm 0.3^{*} \\
(76)\end{array}$ & $\begin{array}{c}23.2 \pm 0.4^{*} \\
(66)\end{array}$ & $\begin{array}{l}5.6 \pm 0.2^{*} \\
(16)\end{array}$ & 0.18 \\
\hline & & Control & $0.01 \mathrm{mM}$ & $0.02 \mathrm{mM}$ & $0.03 \mathrm{mM}$ & $0.05 \mathrm{mM}$ & $0.09 \mathrm{mM}$ & \\
\hline & Myristicin & $\begin{array}{c}35.0 \pm 0.2 \\
(100)\end{array}$ & $\begin{array}{c}28.3 \pm 0.0^{*} \\
(81)\end{array}$ & $\begin{array}{c}25.1 \pm 0.2^{*} \\
(72)\end{array}$ & $\begin{array}{c}21.2 \pm 0.3^{*} \\
(61)\end{array}$ & $\begin{array}{c}18.9 \pm 0.0^{*} \\
(54)\end{array}$ & $\begin{array}{c}6.2 \pm 0.1^{*} \\
\quad(17.7)\end{array}$ & 0.06 \\
\hline
\end{tabular}

Values are mean \pm SE of six replicates. Values in parentheses indicate per cent of enzyme activity with control taken as $100 \%$.

Concentrations $(\mathrm{mM})$ have been expressed as final concentration in the incubation mixture present in the cuvette.

Acetylcholinesterase activity, $\mu$ mole "SH" hydrolyzed $\mathrm{min}^{-1} \mathrm{mg}^{-1}$ protein.

Acid phosphatase activity, $\mu$ mole substrate hydrolyzed $30 \mathrm{~min}^{-1} \mathrm{mg}^{-1}$ protein.

Alkaline phosphatase activity, $\mu$ mole substrate hydrolyzed $30 \mathrm{~min}^{-1} \mathrm{mg}^{-1}$ protein.

* Significant $(P<.05)$ when $t$-test was applied between treated and control groups.

$\left(1.25 \times 10^{-5} \mathrm{M}, 1.8 \times 10^{-5} \mathrm{M}, 3.0 \times 10^{-5} \mathrm{M}\right.$, and $5.4 \times$ $10^{-5} \mathrm{M}$ ) of the substrate 4-nitrophenyl phosphate.

2.3.3. Alkaline Phosphatase. Alkaline phosphatase (ALP) activity in the nervous tissue of Lymnaea acuminata was measured by the method of Bergmeyer [9] as modified by Singh and Agarwal [10]. Tissue homogenate (2\%,w/v) was prepared in ice cold $0.9 \% \mathrm{NaCl}$ and centrifuged at $5000 \mathrm{~g}$ for 15 minutes at $4^{\circ} \mathrm{C}$. The supernatant was used as an enzyme source. $0.1 \mathrm{~mL}$ of enzyme source was added to $1.0 \mathrm{~mL}$ of alkaline buffer substrate $\left(375 \mathrm{mg}\right.$ glycine, $10 \mathrm{mg} \mathrm{MgCl}_{2} \cdot 6 \mathrm{H}_{2} \mathrm{O}$, $165 \mathrm{mg}$ 4-nitrophenyl phosphate disodium salt in $42 \mathrm{~mL}$ of $0.1 \mathrm{~N} \mathrm{NaOH}$ and a mixture was made up to $100 \mathrm{~mL}$ with double distilled water). The incubation mixture was mixed thoroughly and incubated for 30 minutes at $37^{\circ} \mathrm{C} .10 \mathrm{~mL}$ of $0.02 \mathrm{~N} \mathrm{NaOH}$ was then added to the incubation mixture. The yellow colour, developed due to the formation of 4nitrophenol, was determined colorimetrically at $420 \mathrm{~nm}$. Standard curves were drawn with different concentrations of 4-nitrophenol. The ALP activity has been expressed as $\mu$ mole substrate hydrolyzed $30 \mathrm{~min}^{-1} \mathrm{mg}^{-1}$ protein. For the determination of kinetic constants of alkaline phosphatase, in vitro inhibition of the enzyme was carried out at different concentrations $\left(1.2 \times 10^{-5} \mathrm{M}, 1.8 \times 10^{-5} \mathrm{M}, 3.0 \times 10^{-5} \mathrm{M}\right.$, and $5.4 \times 10^{-5} \mathrm{M}$ ) of the substrate 4-nitrophenyl phosphate.

2.3.4. Protein. Protein estimation was carried out by the method of Lowry et al. [11] using bovine serum as a standard.
2.4. Statistical Analysis. Each experiment was replicated at least six times and results were expressed as mean \pm SE of six replicates. Student's $t$-test was applied between control and treated groups to locate significant $(P<.05)$ variations [12].

\section{Results}

\subsection{In Vivo Inhibition of Enzymes}

3.1.1. Acetylcholinesterase. Table 1 shows that AChE activity in the nervous tissue of Lymnaea acuminata of control group was $0.73 \mu$ mole "SH" hydrolyzed $\mathrm{min}^{-1} \mathrm{mg}^{-1}$ protein. In vivo treatment of 40 and $80 \%$ of 24 and 96 h LC $_{50}$ of trimyristin and myristicin caused significant $(P<.05)$ inhibition in AChE activity in the nervous tissue of Lymnaea acuminata. Maximum inhibition of AChE activity (49\% of control) was observed in snails exposed to $80 \%$ of $96 \mathrm{~h} \mathrm{LC}_{50}$ of myristicin (Table 1).

3.1.2. Acid Phosphatase. The acid phosphatase activity in the nervous tissue of Lymnaea acuminata of control group was $32.3 \mu$ mole substrate hydrolyzed $30 \mathrm{~min}^{-1} \mathrm{mg}^{-1}$ protein (Table 1). In vivo treatment of 40 and $80 \%$ of 24 and 96 hours $\mathrm{LC}_{50}$ of trimyristin and myristicin caused significant $(P<.05)$ inhibition in ACP activity in the nervous tissue of Lymnaea acuminata. Maximum inhibition of ACP activity (44\% of control) was observed in snails exposed to $80 \%$ of 96 hours LC $_{50}$ of myristicin (Table 1). 
TABle 3: Kinetic constants $\left(K_{m}\right.$ and $\left.V_{\max }\right)$ of different enzyme inhibitions by trimyristin $(0.09 \mathrm{mM})$ and myristicin $(0.03 \mathrm{mM})$ in snail Lymnaea acuminata.

(a) Michaelis-Menten constant $K_{m}$ and $V_{\max }$ of different enzymes were calculated from Lineweaver-Burk Plots (1/V versus 1/S).

\begin{tabular}{lccccc}
\hline Enzymes & \multicolumn{2}{c}{ Untreated (Control) } & \multicolumn{2}{c}{ Treated (Trimyristin) } & \multicolumn{2}{c}{ Treated (Myristicin) } \\
\hline & $K_{m}$ & $V_{\max }$ & $K_{m}$ & $V_{\max }$ & $K_{m}$ \\
AChE & $3.1 \times 10^{-4}$ & 1.2 & $5.5 \times 10^{-4}$ & 1.0 & $3.8 \times 10^{-4}$ \\
ACP & $1.3 \times 10^{-5}$ & 50.0 & $1.0 \times 10^{-5}$ & 38.4 & $2.1 \times 10^{-5}$ \\
ALP & $2.0 \times 10^{-5}$ & 62.5 & $2.2 \times 10^{-5}$ & 55.5 & 50.00 \\
\hline
\end{tabular}

(b) Michaelis-Menten constant $K_{m}$ and $V_{\max }$ of different enzymes were calculated from nonlinear regression (V versus S).

\begin{tabular}{lccccc}
\hline Enzymes & \multicolumn{2}{c}{ Untreated (Control) } & \multicolumn{2}{c}{ Treated (Trimyristin) } & \multicolumn{2}{c}{ Treated (Myristicin) } \\
\hline & $K_{m}$ & $V_{\max }$ & $K_{m}$ & $V_{\max }$ & $K_{m}$ \\
AChE & $2.9 \times 10^{-4}$ & 1.1 & $4.9 \times 10^{-4}$ & 0.84 & $3.2 \times 10^{-4}$ \\
ACP & $0.9 \times 10^{-5}$ & 40 & $0.8 \times 10^{-5}$ & 33 & $1.9 \times 10^{-5}$ \\
ALP & $1.8 \times 10^{-5}$ & 56 & $1.3 \times 10^{-5}$ & 45 & $1.3 \times 10^{-5}$ \\
\hline
\end{tabular}

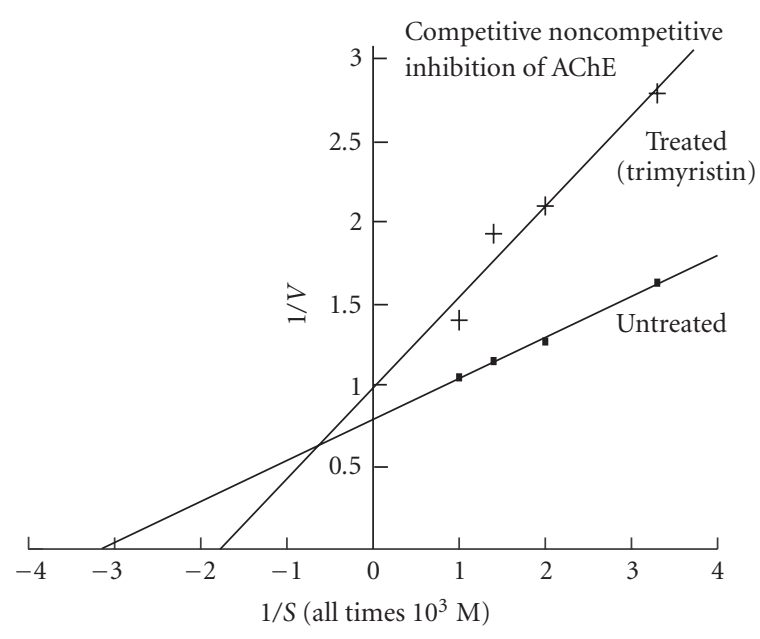

(a)

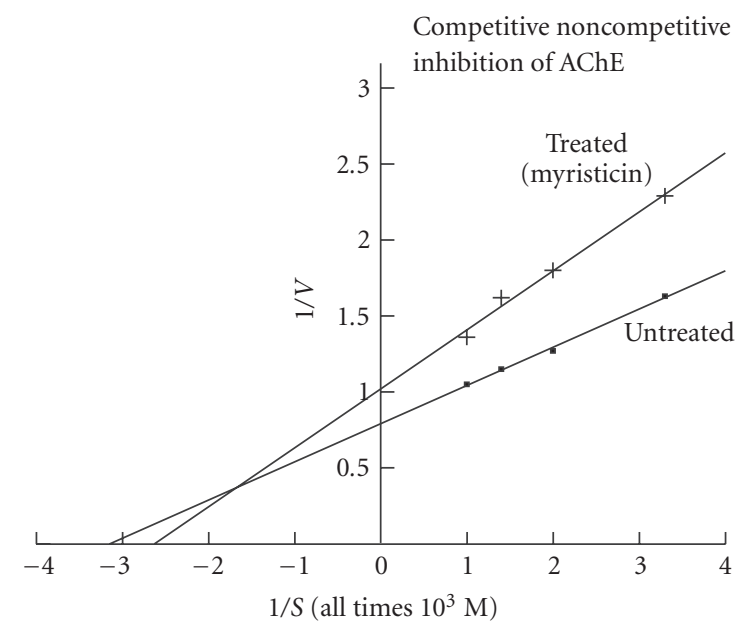

(b)

FIGURE 1: Lineweaver-Burk plots showing the effects of active molluscicidal components trimyristin $(0.09 \mathrm{mM})$ (a) and myristicin $(0.03 \mathrm{mM})$ (b) on the inhibition kinetics of acetylcholinesterase (AChE) activity in the nervous tissue of snail Lymnaea acuminate.

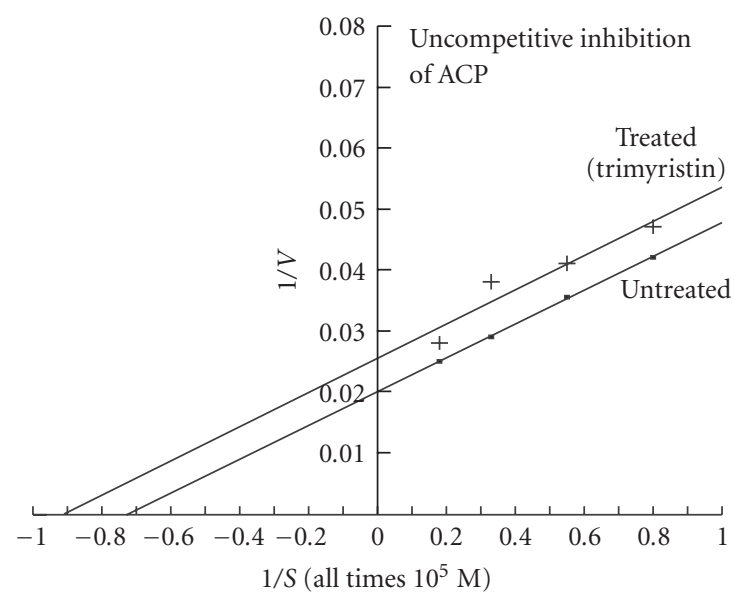

(a)

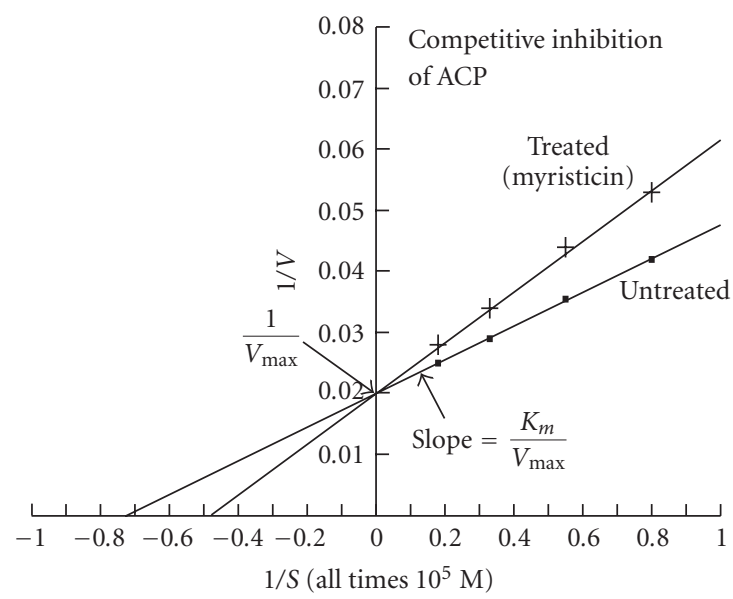

(b)

Figure 2: Lineweaver-Burk plots showing the effects of active molluscicidal components trimyristin $(0.09 \mathrm{mM})$ (a) and myristicin $(0.03 \mathrm{mM})$ (b) on the inhibition kinetics of acetylcholinesterase (ACP) activity in the nervous tissue of snail Lymnaea acuminate. 


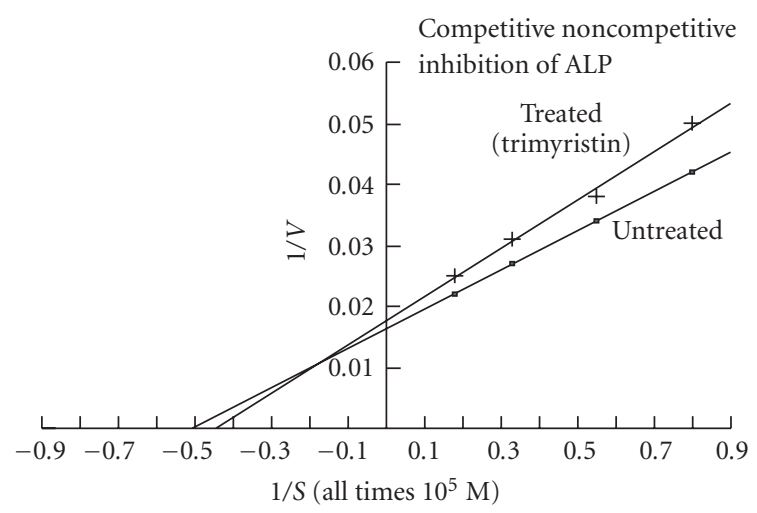

(a)

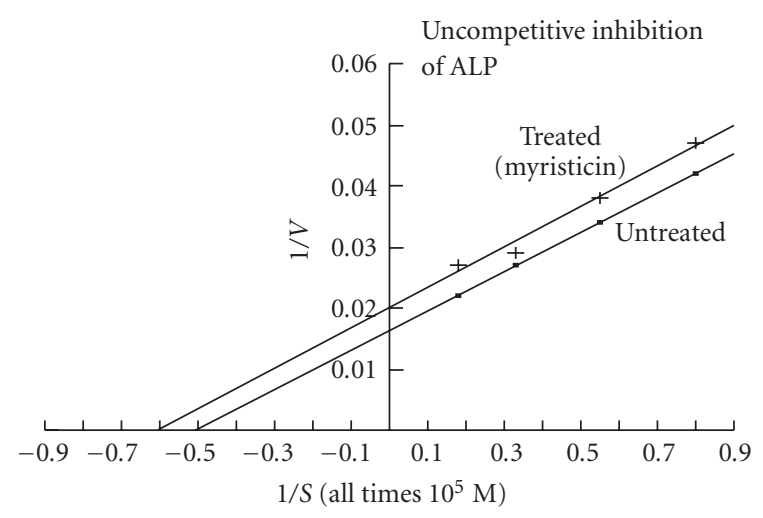

(b)

FIGURE 3: Lineweaver-Burk plots showing the effects of active molluscicidal components trimyristin $(0.09 \mathrm{mM})$ (a) and myristicin $(0.03 \mathrm{mM})$ (b) on the inhibition kinetics of acetylcholinesterase (ALP) activity in the nervous tissue of snail Lymnaea acuminate.

3.1.3. Alkaline Phosphatase. The alkaline phosphatase activity in the nervous tissue of Lymnaea acuminata of control group was $30.0 \mu$ mole substrate hydrolyzed $30 \mathrm{~min}^{-1} \mathrm{mg}^{-1}$ protein (Table 1). In vivo treatment of 40 and $80 \%$ of 24 and $96 \mathrm{~h} \mathrm{LC}_{50}$ of trimyristin and myristicin caused significant $(P<.05)$ inhibition in ALP activity in the nervous tissue of Lymnaea acuminata. Maximum inhibition of ALP activity (52\% of control) was observed in snails exposed to $80 \%$ of $96 \mathrm{~h} \mathrm{LC}_{50}$ of myristicin (Table 1).

3.2. In Vitro Inhibition of Enzymes. In vitro preincubation of $0.04,0.07,0.09,0.1$, and $0.15 \mathrm{mM}$ of trimyristin and 0.01 , $0.02,0.03,0.05$, and $0.09 \mathrm{mM}$ of myristicin caused significant $(P<.05)$ dose dependent inhibition in AChE, ACP, and ALP activities (Table 2). $\mathrm{IC}_{50}$ values of trimyristin/myristicin against AChE, ACP, and ALP were 0.11, 0.16 and 0.18 / 0.03, 0.07 and $0.6 \mathrm{mM}$, respectively (Table 2 ).

The $K_{m}$ and $V_{\max }$ values of uninhibited AChE were $3.17 \times 10^{-4} \mathrm{M}$ and $\mathbf{1 . 2 5} \mu$ mole "SH" hydrolyzed $\mathrm{min}^{-1}$ $\mathrm{mg}^{-1}$ protein, respectively (Table 3 ). $K_{m}$, of trimyristin (Figure 1(a)) and myristicin (Figure 1(b)) inhibited AChE were $5.55 \times 10^{-4} \mathrm{M}$ and $3.84 \times 10^{-4} \mathrm{M}$, respectively. $V_{\max }$ values of trimyristin and myristicin inhibited AChE were $\mathbf{1 . 0}$ and $\mathbf{0 . 9 5} \mu$ mole "SH" hydrolyzed $\mathrm{min}^{-1} \mathrm{mg}^{-1}$ protein, respectively. $K_{m}$ and $V_{\max }$ values of uninhibited ACP were $\mathbf{1 . 3 7} \times 10^{-5} \mathrm{M}$ and $\mathbf{5 0 . 0 0} \mu$ mole substrate hydrolyzed $30 \mathrm{~min}^{-1} \mathrm{mg}^{-1}$ protein, respectively (Table 3$) . K_{m}$ values of trimyristin (Figure 2(a)) and myristicin (Figure 2(b)) inhibited ACP were $1.09 \times 10^{-5} \mathrm{M}$ and $2.12 \times 10^{-5}$ $\mathrm{M}$, respectively. $V_{\max }$ values of trimyristin and myristicin inhibited ACP were $\mathbf{3 8 . 4 6}$ and $\mathbf{5 0} \mu$ mole substrate hydrolyzed $30 \mathrm{~min}^{-1} \mathrm{mg}^{-1}$ protein, respectively. $K_{m}$ and $V_{\max }$ values of uninhibited ALP were $2.0 \times 10^{-5} \mathrm{M}$ and $\mathbf{6 2 . 5 0} \mu$ mole substrate hydrolyzed $30 \mathrm{~min}^{-1} \mathrm{mg}^{-1}$ protein, respectively (Table 3). $K_{m}$ values of trimyristin (Figure 3(a)) and myristicin (Figure 3(b)) inhibited ALP were $2.27 \times 10^{-5} \mathrm{M}$ and $1.66 \times 10^{-5} \mathrm{M}$, respectively. $V_{\max }$ values of trimyristin and myristicin inhibited ALP were $\mathbf{5 5 . 5}$ and $\mathbf{5 0} \mu$ mole substrate hydrolyzed $30 \mathrm{~min}^{-1} \mathrm{mg}^{-1}$ protein, respectively (Table 3 ).

\section{Discussion}

In vivo and in vitro sublethal treatments of trimyristin and myristicin caused a significant inhibition of AChE, ACP and ALP activities in the nervous tissue of Lymnaea acuminata. In in vitro condition, the activity of the enzyme is in the presence of drug. Extent of enzyme inhibition in in vivo and in vitro conditions is the almost same. In in vivo condition titer of the drug at action site may be low, yet it inhibited the enzyme up to the same extent as in in vitro condition. $\mathrm{IC}_{50}$ values of trimyricitin and myristicin clearly indicate that both are more potent inhibitors of AChE than ACP and ALP. AChE inhibition results in accumulation of acetylcholine at the nerve synapses, so that the postsynaptic membrane is in a state of permanent stimulation producing paralysis, ataxia, general lack of coordination in neuromuscular system, and eventual death [13]. It has been reported that n-hexane extract of $M$. fragrans seeds significantly inhibited AChE activity in brain of Swiss albino mice [14] and in in vitro, hydroalcoholic extracts of $M$. fragrans inhibited $50 \%$ of AChE activity at concentration of $100-150 \mu \mathrm{g} / \mathrm{mL}$ using AChE obtained from bovine erythrocytes [15].

Acid phosphatase, a lysosomal enzyme [16], plays an important role in catabolism, pathological necrosis, autolysis, and phagocytosis [17]. Alkaline phosphatase plays a critical role in protein synthesis [18], shell formation, [19] other secretary activities [20], and transport of metabolites [21] in gastropods.

The kinetic study clearly indicates that the inhibition of AChE by trimyristin and myristicin is competitive noncompetitive, as $K_{m}$ and $V_{\max }$ values of uninhibited and inhibited enzymes were different and slopes of inhibited and uninhibited AChE were also changed; both were not parallel to each other. Inhibitions of ACP by trimyristin and ALP, by myristicin are uncompetitive. It is evident from the Lineweaver-Burk plots that the slopes of trimyristin inhibited ACP, myristicin inhibited ALP and uninhibited ACP/ALP were not changed; both were parallel to each other, whereas the intercepts of inhibited and uninhibited ACP/ALP were changed. The $K_{m}$ and $V_{\max }$, of uninhibited and inhibited enzymes were different. Inhibition of ACP by myristicin is competitive, as the $K_{m}$ values of the uninhibited and 
inhibited myristicin enzymes were different and $V_{\max }$ of both were same, as evident from same intercept $\left(1 / V_{\max }\right)$ on the $\mathrm{Y}$ axis of Lineweaver-Burk plots. Inhibition of ALP by trimyristin is also competitive noncompetitive.

Inhibition of AChE, ACP, and ALP by trimyristin and myristicin indicate, different types of inhibition kinetics. It seems that the molluscicidal components of Myristica fragrans kill the snails by inhibiting these enzymes in different ways.

\section{References}

[1] O. Singh and R. A. Agarwal, "Toxicity of certain pesticides to two economic species of snails in northern India," Journal of Economic Entomology, vol. 74, no. 5, pp. 568-571, 1981.

[2] R. L. Sharma, D. N. Dhar, and O. K. Raina, "Studies on the prevalence and laboratory transmission of fascioliasis in animals in the Kashmir valley," British Veterinary Journal, vol. 145, no. 1, pp. 57-61, 1989.

[3] R. A. Agarwal and D. K. Singh, "Harmful gastropods and their control," Acta Hydrochimica et Hydrobiologica, vol. 16, no. 2, pp. 113-138, 1988.

[4] A. Singh, D. K. Singh, T. N. Misra, and R. A. Agarwal, "Molluscicides of plant origin," Biological Agriculture and Horticulture, vol. 13, no. 3, pp. 205-252, 1996.

[5] P. Jaiswal and D. K. Singh, "Molluscicidal activity of Nutmeg and Mace (Myristica fragrans Houtt.) against the vector snail Lymnaea acuminata," Journal of Herbs, Spices \& Medicinal Plants, vol. 15, no. 2, pp. 177-186, 2009.

[6] D. K. Singh and R. A. Agarwal, "Inhibition kinetics of certain organophosphorus and carbamate pesticides on acetylcholinesterase from the snail Lymnaea acuminata," Toxicology Letters, vol. 19, no. 3, pp. 313-319, 1983.

[7] G. L. Ellman, K. D. Courtney, V. Andres Jr., and R. M. Featherstone, "A new and rapid colorimetric determination of acetylcholinesterase activity," Biochemical Pharmacology, vol. 7, no. 2, pp. 88-95, 1961.

[8] D. K. Singh and R. A. Agarwal, "In vivo and in vitro studies on synergism with anticholinesterase pesticides in the snail Lymnaea acuminata," Archives of Environmental Contamination and Toxicology, vol. 12, no. 4, pp. 483-487, 1983.

[9] U. H. Bergmeyer, Methods of Enzymatic Analysis, Academic Press, New York, USA, 1967.

[10] D. K. Singh and R. A. Agarwal, "Toxicity of piperonyl butoxide-carbaryl synergism on the snail Lymnaea acuminata," Internationale Revue der Gesamten Hydrobiologie, vol. 74, no. 6, pp. 689-699, 1989.

[11] O. H. Lowry, N. J. Rosenbrough, A. L. Farr, and R. J. Randall, "Protein measurement with folin phenol reagent," The Journal of Biological Chemistry, vol. 193, no. 1, pp. 265-275, 1951.

[12] R. R. Sokal and F. J. Rohlf, Introduction to Biostatistics, W. H. Freeman, San Francisco, Calif, USA, 1973.

[13] F. Matsumura, Toxicology of Insecticides, Plenum Press, New York, NY, USA, 2nd edition, 1985.

[14] D. Dhingra, M. Parle, and S. K. Kulkarni, "Comparative brain cholinesterase-inhibiting activity of Glycyrrhiza glabra, Myristica fragrans, ascorbic acid, metrifonate in mice," Journal of Medicinal Food, vol. 9, no. 2, pp. 281-283, 2006.

[15] P. K. Mukherjee, V. Kumar, and P. J. Houghton, "Screening of Indian medicinal plants for acetylcholinesterase inhibitory activity," Phytotherapy Research, vol. 21, no. 12, pp. 1142-1145, 2007.
[16] P. Aruna, C. S. Chetty, R. C. Naidu, and K. S. Swami, "Acid phosphatase activity in Indian apple snail Pila globosa (Swainson), during aestivation and starvation stress," Proceedings of the Indian Academy of Sciences, vol. 88, pp. 363-365, 1979.

[17] M. B. Abou-Donia, "Increased acid phosphatase activity in hens following an oral dose of leptophos," Toxicology Letters, vol. 2, no. 4, pp. 199-203, 1978.

[18] B. Pilo, M. V. Asnani, and R. V. Shah, "Studies on wound healing and repair in pigeon liver. III. Histochemical studies on the acid and alkaline phosphatases during the processes," Journal of Animal Morphology and Physiology, vol. 19, no. 2, pp. 205-212, 1972.

[19] L. P. M. Timmermans, "Studies on shell formation in mollusks," Netherlands Journal of Zoology, vol. 19, pp. 17-36, 1969.

[20] A. M. Ibrahim, M. G. Higazi, and E. S. Demian, "Histochemical localization of alkaline phosphatase activity in the alimentary tract of the snail Marisa cornuarietis (L.)," Bulletin of the Zoological Society of Egypt, vol. 26, pp. 94-105, 1974.

[21] A. Vorbrodt, "The role of phosphate in intracellular metabolism," Postẹpy Higieny I Medycyny Doświadczalnej, vol. 13, pp. 200-206, 1959. 

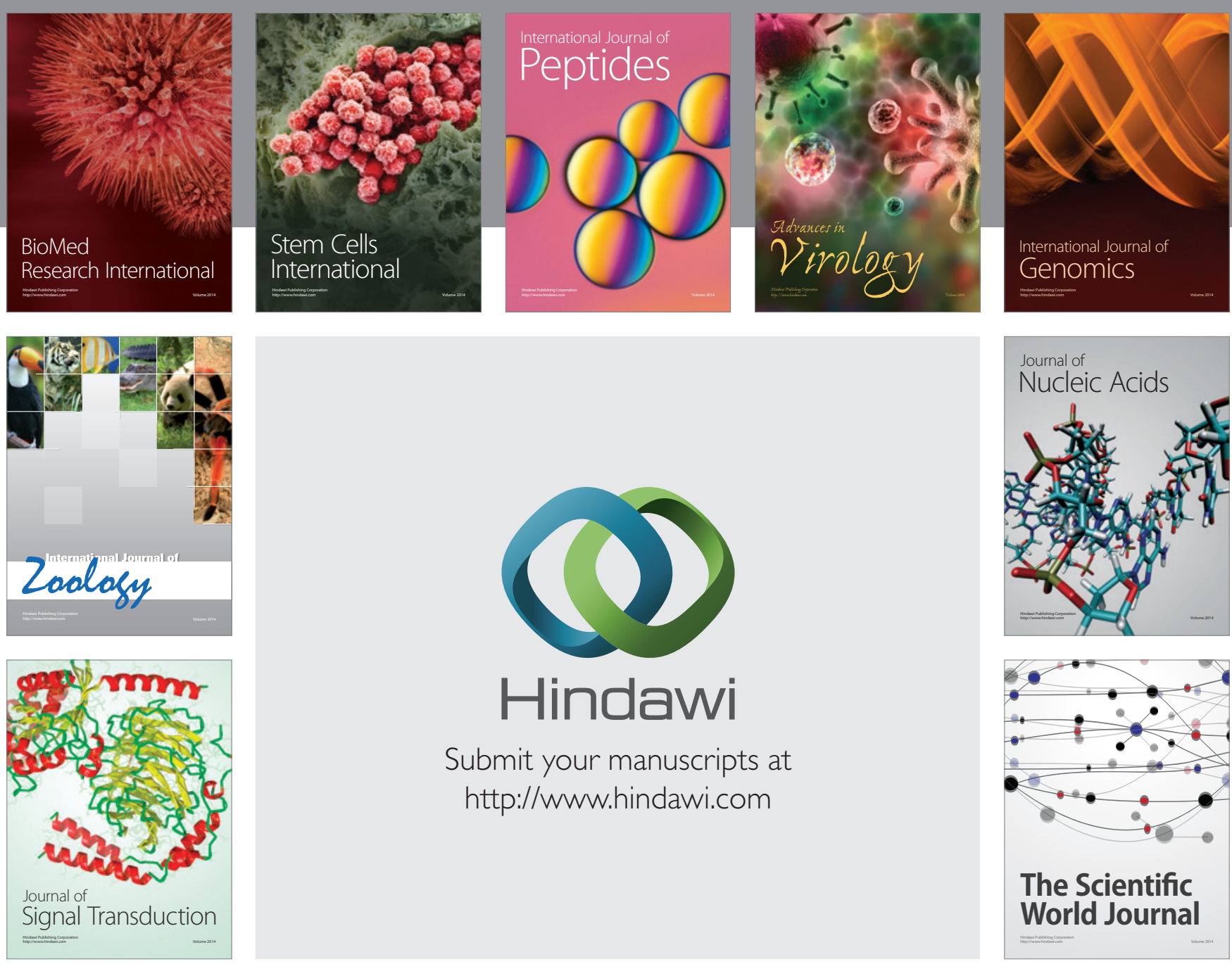

Submit your manuscripts at

http://www.hindawi.com
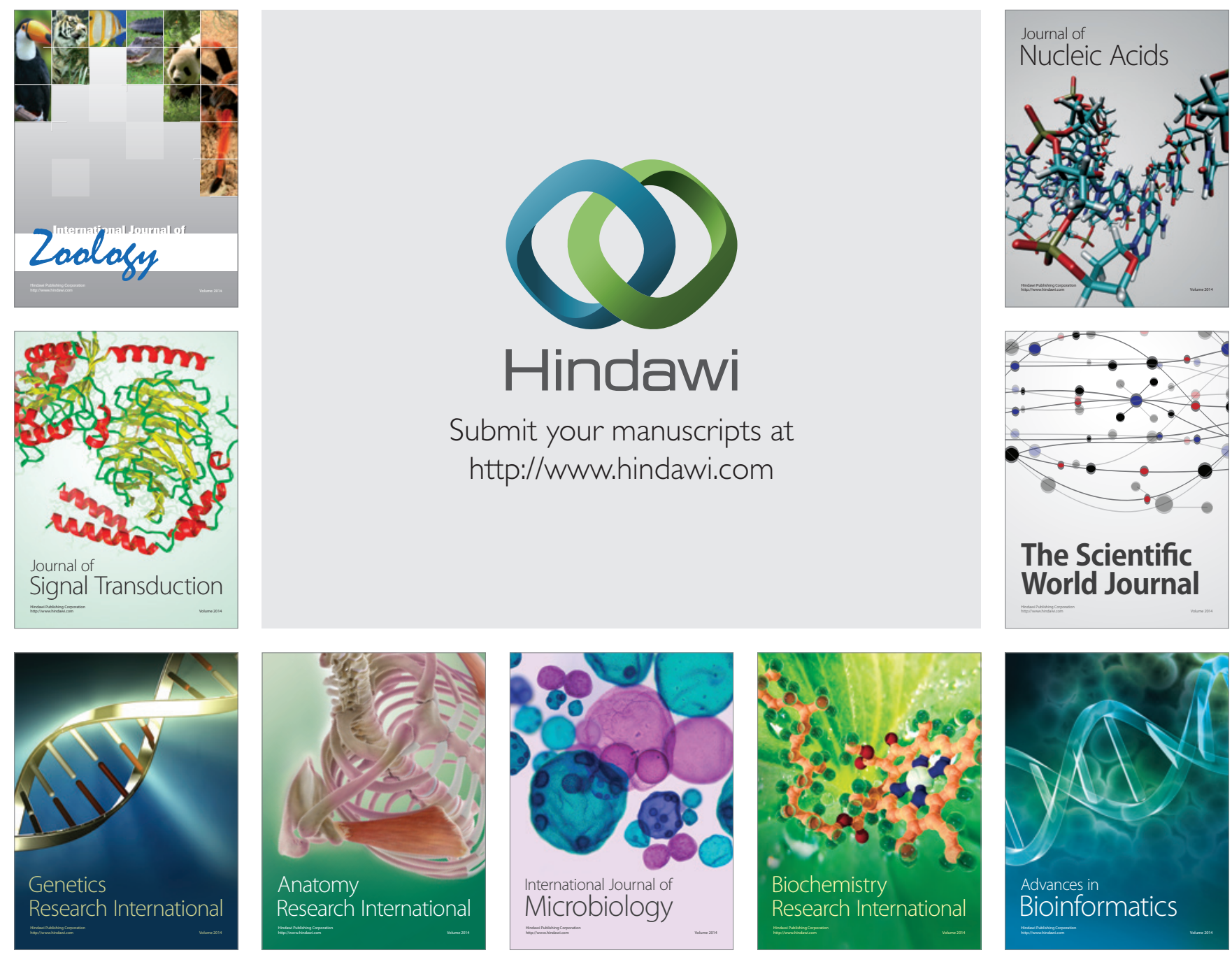

The Scientific World Journal
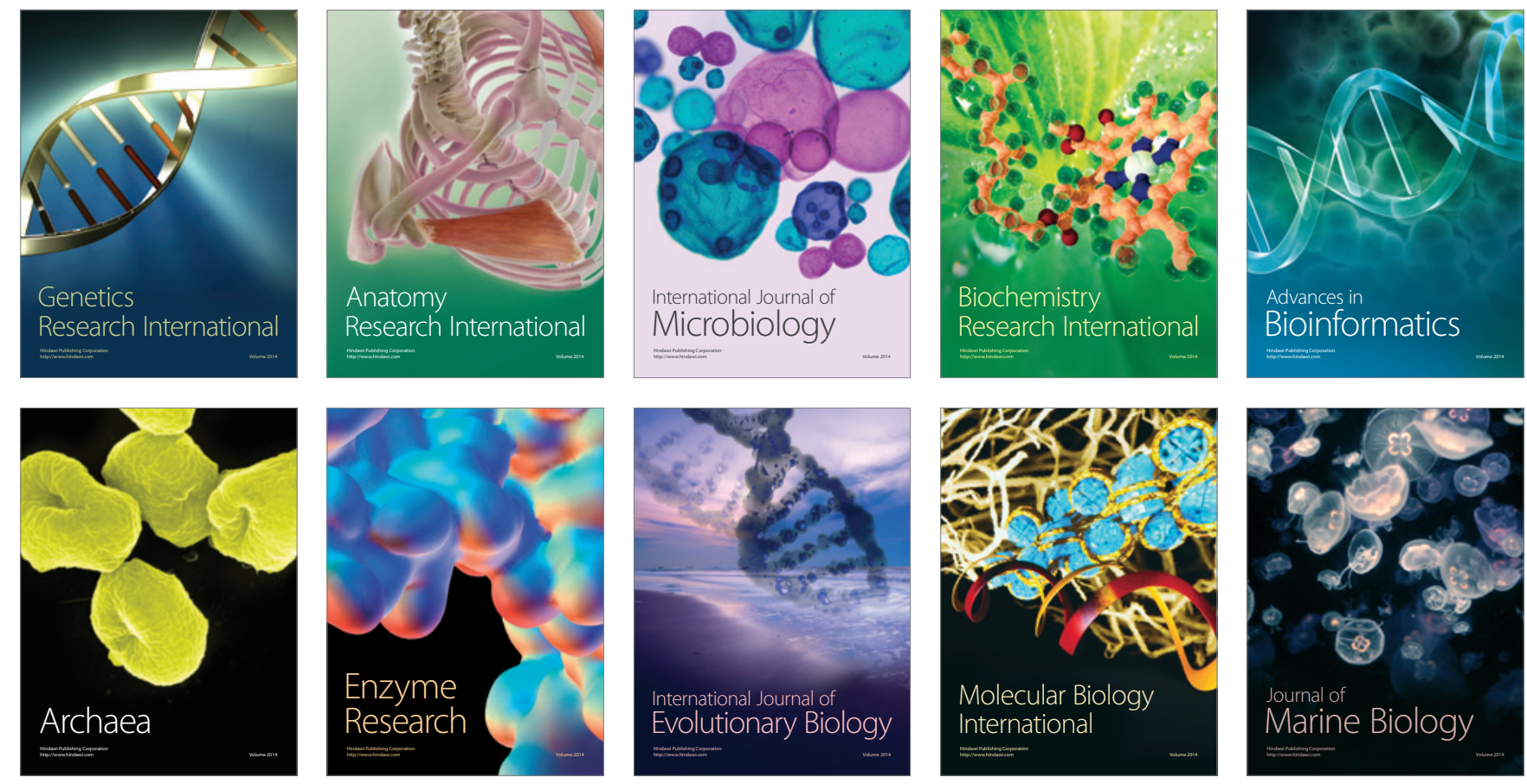